\title{
Transmission Electron Microscopy (TEM) Through Focused ION Beam (FIB) from Vitrified Chromium Wastes
}

\author{
S. Ballesteros-Elizondo*¹, J. R. Parga-Torres ${ }^{2}$, J. Ma. Rincón-López ${ }^{3}$, E. Palacios-González ${ }^{4}$ \\ 1,2 Instituto Tecnológico de Saltillo, Departamento de Metal-Mecánica \\ Blvd. V. Carranza 2400, Saltillo, Coahuila, Mexico. C.P 25230 \\ *sballes@ciateq.mx \\ ${ }^{1}$ Centro de Tecnología Avanzada-CIATEQ, AC \\ Laboratorio de Equipos de Proceso \\ Unidad Bernardo Quintana, Av. Manantiales 23-A \\ Parque Industrial Bernardo Quintana \\ El Marqués 26246, Querétaro, Querétaro, Mexico \\ ${ }^{3}$ Instituto de Ciencias de la Construcción Eduardo Torroja-CSIC \\ Grupo/Laboratorio de Materiales Vítreos y Cerámicos y \\ Departamento de Sistemas Constructivos en la Edificación \\ Serrano Galvache 4, Madrid, Spain. C.P. 28033 \\ ${ }^{4}$ Instituto Mexicano del Petróleo \\ Laboratorio de Microscopía Electrónica de Ultra Alta Resolución-UHREM-L \\ Eje central Lázaro Cárdenas, Col. San Bartolo Atepehuacan, México D.F. 07730
}

\begin{abstract}
This study shows how the Focused Ion Beam (FIB) has been applied to vitrified materials obtained from chromium wastes. Due to the issues arising during conventional Ar+ ion milling, it was necessary to thin these samples using FIB. Difficulties came from the heterogeneous size between chromium spinels and the residual glass phase. The FIB was applied to obtain thin foils from vitrified materials. These brittle and heterogeneous samples result in specimens with many perforations and chipping when using conventional thinning below 100 nanometers. Alternatively, FIB allowed thinning in the range of 60 - 80 nanometers from specifically selected areas such as the areas containing spinel crystals $\mathrm{Mg}(\mathrm{Al}, \mathrm{Cr}) 2 \mathrm{O} 4$ in order to facilitate the final Transmission Electron Microscopy (TEM) observations. In this paper, FIB is shown to be a very powerful microtool as a brittle samples preparation method as well as providing an alternative way for performing conventional ceramography and Ar+ ion milling. FIB is a much less destructive method with greater observed capacity in the quantity and analysis of microcrystalline phases.
\end{abstract}

Keywords: Focused Ion beam (FIB), Transmission Electron Microscopy (TEM), Selected Area Diffraction Patterns(SADP).

\section{RESUMEN}

Este estudio muestra como el Focused Ion Beam (FIB) ha sido aplicado a materiales obtenidos de la vitrificación de residuos de cromo. Debido a problemas de desprendimiento de material cuando se aplicó el proceso de adelgazamiento por el método convencional de $\mathrm{Ar}^{+}$ion milling fue necesario preparar las muestras usando FIB. Las dificultades se deben al tamaño heterogéneo de las espinelas de cromo y presencia de la fase vítrea residual. EI FIB se utilizó para obtener laminillas delgadas de material vitrificado. Las muestras frágiles y heterogéneas que resultan del corte y pulido presentan muchas perforaciones y rebabas cuando se utiliza el método convencional de adelgazamiento a espesores por debajo de los $100 \mathrm{~nm}$. Como método alternativo, el FIB permitió el adelgazamiento de muestras en el orden de 60-80 nm en áreas específicamente seleccionadas conteniendo cristales de espinelas $\mathrm{Mg}(\mathrm{Al}, \mathrm{Cr})_{2} \mathrm{O}_{4}$ con el fin de facilitar las observaciones en Microscopía Electrónica de Transmisión (MET). Este artículo muestra cómo el FIB representa una micro-herramienta muy poderosa como método de preparación de muestras para corte y adelgazamiento de muestras frágiles, además de ser una alternativa de mayor alcance que la preparación de muestras por ceramografía o por el método de desbaste y pulido con iones $\mathrm{Ar}^{+}$. El método FIB es mucho menos destructivo y con mayor capacidad para observar aéreas de la muestra en cuanto a la cantidad y análisis de las fases microcristalinas presentes. 


\section{Introduction}

Today, producing inert and recyclable materials from the vitrification of wastes and, at the same time, to immobilize toxic elements in glass or glass ceramics is a research topic of great interest. Though the material obtained initially was partially fractured blocks, a specific methodology has been developed in order to obtain building materials (bricks and tiles mainly). For this application, it is essential to determine the microstructure composition in order to understand the mechanical and chemical behavior and to improve the performance of these new types of materials. From this point of view, the Electron Microscopy investigation can produce valuable complementary data about the mineralogy of the phases, both crystalline and amorphous, or the residual glassy phase microstructure and composition [1][2]. In this case, research by TEM/ EDS is currently being carried out to overcome the difficulties of the TEM specimen preparation for these types of materials. A complementary study for post preparation of lamellar samples containing typical microstructures of vitreous materials was carried out via TEM including diffraction (SADP, selected area diffraction patterns) to complete

\section{Materials and methods}

Two types of glass ceramics were investigated by Electron Microscopy; one of them was a glass ceramic called $\mathrm{VC}_{2}$ which was partially crystallized. The other was a glass ceramic called TM which was totally devitrified by controlled nucleation and crystal growth. After processing these respective materials, the general mineralogical composition of these materials was shown to be augite $\left(\mathrm{CaMgAl}_{2} \mathrm{Si}_{2} \mathrm{O}_{6}\right.$, pyroxene $\left(\mathrm{CaMgSi}_{2} \mathrm{O}_{6}\right)$ and spinel crystallizations $\mathrm{Mg}(\mathrm{Cr}, \mathrm{Al})_{2} \mathrm{O}_{4}$ embedded into a residual glassy phase[3].

The TEM study samples were prepared as thin foils by Focused Ion Beam (FIB-SEM) method [4]. The method of sample preparation was based on the ion bombardment for thinning a part of the slab in a Scanning Electron Microscope Dual Beam
(SEM-FIB Nova 200 Nanolab, FEI Company). The procedures for thinning a specific area to within nanometers were precisely determined. The whole process of selecting areas of interest then, cutting and polishing the slab, was monitored through an infrared camera positioned inside the vacuum chamber of the microscope. This microscope is also equipped with an electron beam gun and a Gallium ion gun, with power supplies (one platinum and one carbon), as well as a tool for handling of samples.

The method of sample preparation is based on the $\mathrm{Ga}+$ ion beam thinning, in which a specific area is precisely selected within a size range of nanometers without modifying the microstructural features. After selecting the area of interest, a platinum strip is deposited in order to protect the area and to select an area for welding the resultant sample. Then the geometry is selected as well as the dimensions of the micro-and nanosized areas for cutting. Next, the selected area is cut, then, smoothed and polished on both sides. After, it is welded to the tip of the needle of the micromanipulator, the sample is placed and welded in a grid shaped as a crescent moon, which is consistent with the sample holder used in the Transmission Electron Microscope (TEM). Once the sample on the grid is in position and welded, it must be polished and thinned to a thickness of less than 100 nanometers, which is the recommended thickness for observation by TEM. Figure 1 shows the sequence for SEM-FIB preparation.

The operating conditions for TEM and microdiffraction observation in both thinned samples post SEM-FIB, VC2 and TM were obtained by using Zeiss TEM- LEO 910 equipment working at $100 \mathrm{kV}$ which has been used for observations of thin specimens from glass ceramic samples post FIB. The electron diffraction from different areas has been carried out under SADP conditions with camera length $L=720 \mathrm{~mm}$. Standard patterns obtained from evaporated gold show ring diffraction patterns were used for calibration of the electron diffraction, giving rise to a constant of $L \lambda=26.60 \mathrm{~mm} . \AA$ for the same camera length in the operational conditions of Zeiss TEM-LEO 910 [5]. 


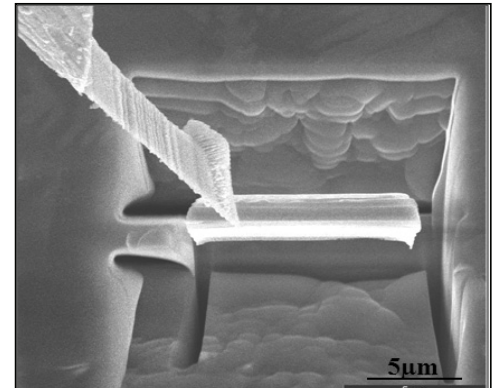

a)

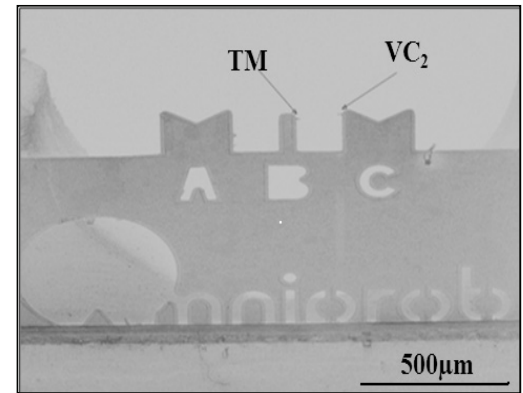

b)

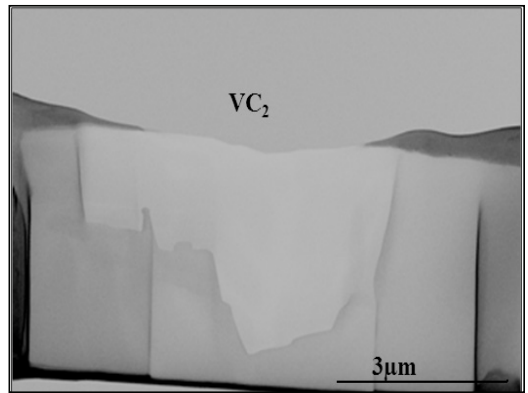

c)

Figure 1. Three important steps for FIB- SEM preparation: a) sample extraction, b) welded samples TM and $\mathrm{VC}_{2}$ in $\mathrm{Cu}$ slot grid, and c) final sample thinning of $\mathrm{VC}_{2}$ sample in the range 80-100 nanometers.

\section{Results and discussion}

Figure 1a shows both a slight bulging of material in a FIB cross-sectional surface sample extraction. This effect can be due to the presence of a great number of microcrystalline devitrified phases and a residual minor amount of the amorphous vitreous phase. Figure $1 \mathrm{~b}$ shows, at a low magnification, the location of the thinned samples in the relative half moon $\mathrm{Cu}$ grid. Figure1c shows the final appearance after FIB grinding and thinning of the glass ceramic $\mathrm{VC}_{2}$ sample.

Figure $2 \mathrm{a}$ shows the final $\mathrm{VC}_{2}$ thinned sample with the existence of a spontaneous spalling effect during preparation via SEM-FIB. Contrast lines can be seen in the augite due to stress concentration fields inside the pyroxene matrix. In another region of the TEM image, augite dendrite crystallization was observed, which exhibits a diffraction pattern (SADP) of augite crystal oriented according to the [001] axis zone (Figure $2 b$ ).

TEM micrograph (Figure 2c) shows by Bright Field (BF) image droplets of liquid-liquid phase separation as well as dark contrast and bubbles produced by electron irradiation, and the stress field in the residual glassy phase.

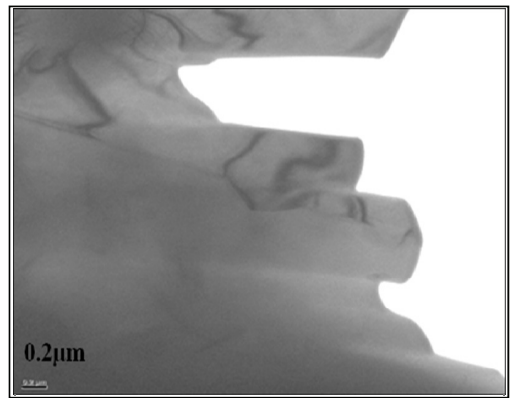

a)

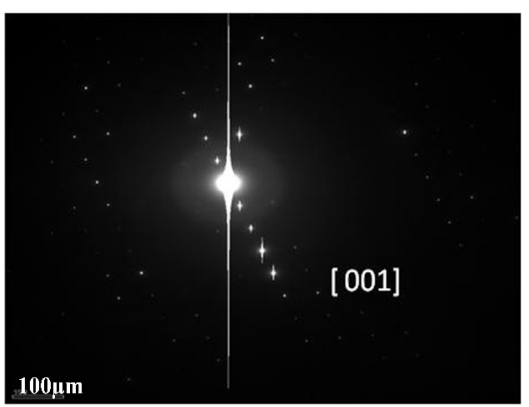

b)

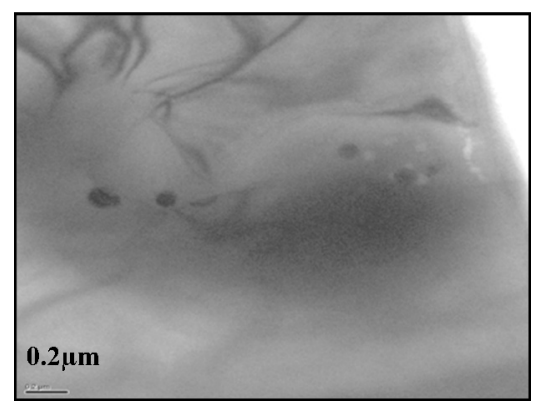

c)

Figure 2. TEM observation and electron diffraction of thinned foil of sample VC2 by SEM-FIB. 


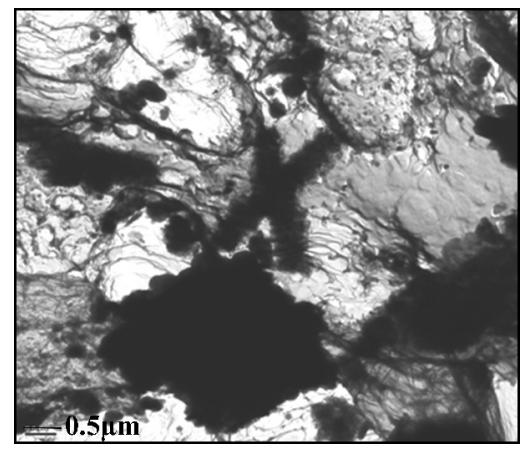

a)

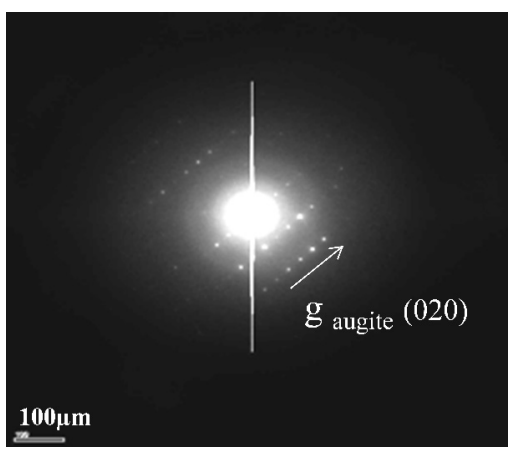

b)

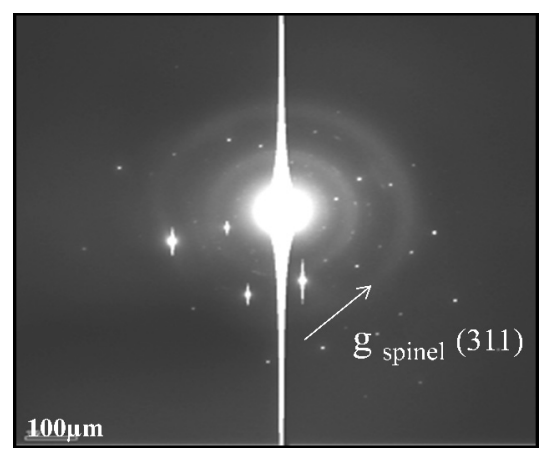

c)

Figure 3. TEM observation of pyroxene (augite) dark cross and spinel angular dark crystals with corresponding SADP of thinned foil of sample TM by SEM-FIB.

Figure 3a, obtained by BF image shows dark contrasted polyhedric spinel and augite (pyroxene) crystals in the TM sample. The corresponding diffraction patterns (Figure $3 \mathrm{~b}$ and $\mathrm{c}$ ) are analyzed with the diffraction vectors $\mathrm{g}=(020)$ and vector $\mathrm{g}=$ (311) in both crystalline phases.

Therefore, difficulties of specimen preparation arising from conventional thinning by $\mathrm{Ar}^{+}$milling of glass and glass ceramic specimens have been overcome. The viscoelastic behavior expected in these materials give rise to a significant residual stress field which can drive material diffusion over time, leading to local stress relaxation and viscoelastic creep associated with surface cracks and also crystals of diverse size in the analyzed glass ceramics [6][7]. TEM micrographs show droplets of liquid-liquid phase separation in BF images, dark contrast and bubbles produced by electron irradiation as well as stress fields produced in the residual glassy phase of these glass ceramics [8][9]. The proposed method of specimen preparation SEM-FIB for TEM observations is an acceptable technical solution in order to obtain microstructure and phase information of glass ceramics with large, heterogeneous phases that are produced during vitrification of wastes with higher chromium content.

\section{Results and discussion}

According to the results obtained, it was concluded that by TEM observations the glass and glass ceramics obtained from the vitrification of industrial chromium waste contain areas of glass-in-glass phase separation and crystalline phases of spinel $\mathrm{Mg}(\mathrm{Cr}, \mathrm{Al})_{2} \mathrm{O}_{4}$ and pyroxenes (augite $\mathrm{CaMgSi}_{2} \mathrm{O}_{6}$ ) This phenomenon is related to toxic chromium immobilization in the spinel structure. Large/ small size heterogeneity between spinel and augite phases involves many difficulties for the TEM thinning specimen preparation. It has been demonstrated here for the first time that this can be overcome through the use of complementary methods such as SEM-FIB. This new method has been developed and applied to these brittle and heterogeneous materials of different grain size and microstructure. In addition, the SEM -FIB can ease the thinning of selected areas such as the large spinel crystals in order to provide the final TEM observations and analysis. 


\section{References}

[1] Rincon $\mathrm{J} \mathrm{Ma}$. and Romero $\mathrm{M}$, Microstructural characterization by electron microscopy of ceramics and glasses, Microscopy and Analysis, nov. (1996) 23-25

[2] Doig $P$ and Flewitt PEJ, The role of specimen and instrumental parameters in STEM- EDS x-ray microanalysis of thin foils. Journal of Microscopy. (1983)130(3):377-388

[3] Ballesteros S, Parga J.R, Delgado A. ,Cano, Rincón J.Ma. Electron Microscopy study of vitrified materials from chromite contaminated soil and confinated mud waste with chrome III \& VI. Joint Meeting Portuguese of the Spanish Microscopies, 2009, pp289

[4] Munroe P R, The application of focused ion beam microscopy in the material sciences. Materials Characterization 60(2009) pp1-13

[5] Maru M M, Peripolli S B, Gomes L S, Oliveira A M, Silva R F, Subsurface analysis of a worn bearing steel after FIB preparation. Joint Meeting Portuguese of the Spanish Microscopies, 2009 , pp245

[6] Rincón J Ma and Romero M, Characterization of mullite/ZrO2 high-toughness ceramic materials by medium voltage analytical electron microscopy, Materials Characterization 45 (2000) 2, 117- 123.

[7] Elfallagh F, Inkson B J, 3D analysis of crack morphologies in silicate glass using FIB tomograph. Journal of the European Ceramic Society 29. (2009) 47-52

[8] Lucille A. Giannuzzi, RemcoGeurts and Jan Ringnalda $2 \mathrm{keV} \mathrm{Ga}+\mathrm{FIB}$ Milling for Reducting Amorphous Damage in Silicon, Microsc. Microanal. 11 (Suppl 2) (2005) 828-829.

[9] De Natale J F, Radiation damage in nuclear waste glass, Glasses and Glass-Ceramics for Nuclear Waste Management, 1987, Scientific Editor: J. Ma. Rincón, Ed. Ciemat and CSIC, Madrid pp 179-205.

\section{Acknowledgment}

Thanks are due to Instituto Mexicano del Petróleo (Mexican Petroleum Institute), Laboratorio de Microscopía Electrónica de Ultra Alta Resolución (Ultra High Resolution Electron Microscopy Laboratory), UHREM-L, and Vicente Garibay for the facilities to prepare the FIB-SEM specimens. Thanks to the Wood Institute of Castilla la Mancha, Toledo, Spain for access to the SEM Lab as well as to Instituto de Ciencias Ambientales (Institute of Enviromental Sciences), CSIC,
(Carmen Ascaso) Madrid for facilities to perform the TEM work. The authors wish to acknowledge Miss Sarah Bruce of the Peace Corps in reviewing the English translation. 


\section{Authors' Biographies}

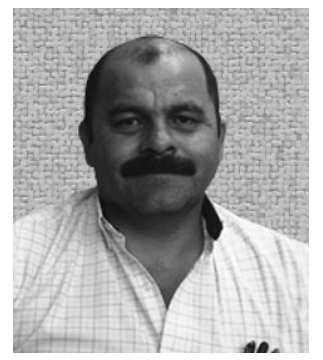

\section{Sergio BALLESTEROS-ELIZONDO}

He received his undergraduate degree in the field of metallurgical chemical engineering from the School of Metallurgy at Universidad Autónoma de Coahuila (Autonomous University of Coahuila), UadeC, in northern Mexico. He started his career as a researcher on metallic coatings for the restoration of high temperature turbine components in COMIMSA. He holds a master's degree in metallurgical engineering from Instituto Tecnológico de Saltillo (Technological Institute of Saltillo). He has worked at Altos Hornos de México SA (AHMSA), Industrias Monterrey (IMSA), Monclova Plant, Regiocal, SA, Monterrey. In recent years, he has been project leader of the Department of Process Equipment at CIATEQ. Some current projects of interest include research and development of processes for the use, recovery and recycling of waste generated by the mechanical and metallurgy industry. He has authored several technical papers at the national and international level. $\mathrm{He}$ is currently a doctoral candidate in materials science from Instituto Tecnológico de Saltillo.

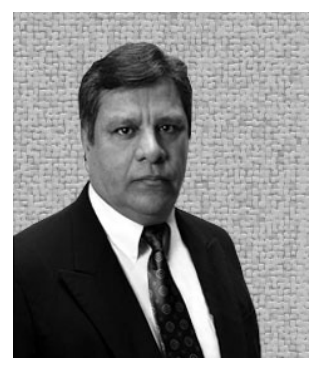

\section{José R. PARGA-TORRES}

Dr. José Refugio Parga-Torres studied at Instituto Tecnológico de La Laguna (Technological Institute of La Laguna) and graduated in chemical engineering in 1974. He received his Master's of Science degree in 1987 from the Colorado School of Mines and his doctorate degree in 1987 from the University of Utah, from both with a specialization in extractive metallurgy. Dr. José Refugio Parga-Torres is a member of the National Research System, level II, with more than 30 years as a research professor in graduate studies at Instituto Tecnológico de Saltillo (Technological institute of Saltillo). He has advised more than 50 students through graduate-level engineering programs for successful completion of their master's and PhD degrees. Two of these PhD students and several other master's students were recognized by Secretaría de Educación Pública (Mexican Education Secretariat), SEP, and Dirección General de Educación Superior Tecnológica (Technological Higher Education General Administration), DGEST, as Best Graduate Thesis Nationwide. Dr. José Refugio Parga-Torres has also written more than 90 articles in his professional field. He earned the "Benito Juarez Garcia National Award 2007" as well as the "Medal for Meritorious Teaching 2007" from the government of Coahuila. In 2005, he received the distinction as an "Ambassador of Science" as well as being recognized as an "Outstanding Coahuilense" both by the COECYT (State Council of Science and Technology). Internationally, he has received a number of awards, including the "International Award for Excellence Frontier" in 1999, "TMS" in 2008 and the "Gill Chair Award" in 2001 by U.S. Foundations 


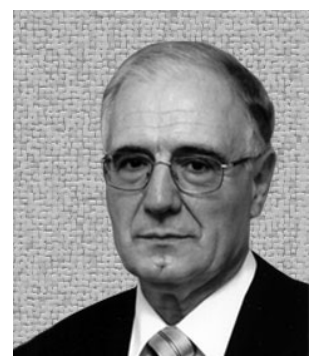

\section{Jesús Ma. RINCON-LÓPEZ}

He got his doctoral degree in chemistry from Universidad Complutense de Madrid (University Complutense of Madrid) in 1982 and has been Researcher Staff Professor at CSIC, Spain, since 2001. From 1984 to 1985, he was Visiting Associate Professor at University of California, Berkeley, USA with a research on analytical and high resolution electron microscopy of advanced ceramics from the zirconia/ mullite and glass-ceramics. Dr. Rincón has more than 40 year experience in glasses and glass-ceramics research, processing and characterization. He has authored 150 papers published in international ISI bulletins, more than 40 papers in Spanish bulletins, 100 book chapters, 7 monographic books and several patents. $\mathrm{He}$ has supervised 8 doctoral theses on glasses and glass-ceramics, being the author of the first book on glass-in-glass phase separation on glasses edited by the Spanish SECV. From 1988 to 1992, he was the General Secretary and Editor-in-Chief of the Spanish Glass and Ceramic Society. He maintains cooperation with Mexico, Argentina, Brazil, Italy, Germany, Bulgaria and Poland. Since 1991, he has collaborated as partner in European Projects on recycling of industrial wastes. Also, he worked for UNIDO- ICS, Trieste and IAEA, Vienna. He is leader of several industry projects on nucleation and crystallization in glasses and ceramics (mainly tile industries). From 2006 to 2010, he has been the Head of the Department of Construction Systems, CSIC, IETCC and has been recently named Vice President of the Spanish Scientists Society (AEC).

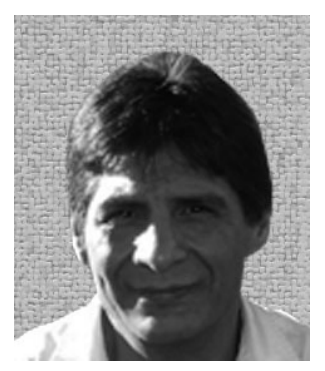

\section{Eduardo PALACIOS-GONZÁLEZ}

He graduated in geological engineering in 1983 from Universidad Nacional Autónoma de México (National Autonomous University of Mexico), UNAM. He received his Doctor of Philosophy (Ph. D.) degree in geological engineering in 1991 from Leningrade Mining Institute, San Petersburg, Russia. He has collaborated on projects related to the exploration, exploitation and processing of oil resources at Instituto Mexicano del Petróleo (Mexican Institute of Petroleum), MPI from 2000 to present. Currently, he is in charge of the microand nanocharacterization of the geological and synthetic materials, in the Ultra High Resolution Microscopy Laboratory, at the MPI. 